\title{
Pemodelan Sistem Informasi Order Fullfillment Pada Perusahaan Diesel Menggunakan Enterprise Architecture Planning Archimate
}

\author{
Nirwan $^{1 *}$, Johanes Fernandes Andry ${ }^{2}$ \\ ${ }^{1,2}$ Jurusan Sistem Informasi, Fakultas Teknologi dan Desain, Universitas Bunda Mulia, Jakarta, Indonesia \\ ${ }^{1,2}$ Jln. Lodan Raya, Ancol, Kota Jakarta Utara, Daerah Khusus Ibukota Jakarta 14430, Indonesia \\ email: ${ }^{1}$ nirwan_bean@yahoo.com, ${ }^{2}$ jandry@bundamulia.ac.id
}

Copyright $@ 2019$, Politeknik Harapan Bersama, Tegal

\begin{abstract}
A diesel company that currently has three business segments: marine engines, industrial machinery and industrial generating sets. For the wider public, this diesel company is very popular in marine engines and is a world-leading innovation, such as Aquamatic drives and counter-rotating propellers, Duoprop. This diesel company is able to create high-tech products and support the global market of industries, such as diesel-operated generators, cranes and container handlers. This company has seen good business prospects for the company in the future. For the East Asia region, the head office uses Singapore to manage business operations including as warehouse area, sales and marketing activities. The more rapid competition becomes the impact of competitors, the first problem identified in this study will be mapping application planning to support the needs of existing corporate governance through enterprise architecture planning. The method used to plan the entire system will use archimate modeling, included are business, application and technology layer which will produce modeling order fulfillment applications. In this problem, the focus will be on application development factors that can help optimize business process problems such as: inputting data activities, competencies and responsibilities, time, constraints and technical documentation, standards applied, reports produced for various decision-making processes, internal communication and external, and other resources. These problems can enable the implementation of enterprise architecture methods into the company by using and managing data into enterprise architecture analysis and project planning for marketing strategies, corporate architectural analysis patterns are expected to overcome the company's problems.
\end{abstract}

Abstrak - Sebuah perusahaan diesel yang saat ini memiliki tiga segmen bisnis: mesin kelautan, mesin industri dan industri untuk Generating set. Untuk publik yang lebih luas, perusahaan diesel ini sangat populer di mesin kelautan dan terkemuka dunia inovasi, seperti drive Aquamatic dan baling-baling counterrotating, Duoprop. Perusahaan diesel ini mampu menciptakan produk teknologi tinggi serta dukungan pasar global industri, seperti Genset yang dioperasikan dengan diesel, crane dan penangan kontainer. Perusahaan ini telah melihat prospek bisnis yang baik bagi perusahaan di masa depan. Untuk wilayah Asia Timur, kantor pusat menggunakan Singapura untuk mengelola operasi bisnis termasuk sebagai gudang wilayah, kegiatan penjualan dan pemasaran. Semakin pesat nya persaingan menjadi sebagai dampak dari pesaing, masalah pertama yang diidentifikasi dalam penelitian ini akan

\footnotetext{
*) penulis korespondensi: Nirwan

Email: nriwan_bean@yahoo.com
}

memetakan perencanaan aplikasi untuk mendukung kebutuhan dalam tata kelola yang ada di perusahaan melalui perencanaan enterprise architecture. Metode yang digunakan untuk merencanakan seluruh sistem akan menggunakan pemodelan archimate, terdiri dari busines, applikasi dan teknologi layer yang akan menghasilkan pemodelan aplikasi order fulfillment. Fokus masalah pada faktor pengembangan aplikasi yang dapat membantu mengoptimalkan permasalahan proses bisnis seperti: kegiatan penginputan data, kompetensi dan tanggung jawab, waktu, kendala dan teknis dokumentasi, standar yang diterapkan, laporan yang dihasilkan untuk berbagai proses pengambilan keputusan, komunikasi internal dan eksternal, dan sumber daya lainnya. Dari permasalahan tersebut bisa memungkinkan pengimplementasian metode enterprise arsitektur ke dalam perusahaan dengan menggunakan dan mengelola data kedalam analisis arsitektur perusahaan dan proyek perencanaan untuk strategi pemasaran, pola analisis arsitektur perusahaan di harapkan dapat mengatasi masalah perusahaan.

Kata Kunci - Enterprise Architecture, Archimate, Order Fulfillment.

\section{PENDAHULUAN}

Pembangkit listrik atau diesel unit untuk menghasilkan listrik dengan beberapa proses sistem mekanis yang mengubah sumber daya alam; air, udara, uap, matahari dan sumber apa pun untuk menjadi tenaga listrik dan mendistribusikannya. Namun, untuk area dan lokasi yang terbatas, diesel lebih disukai karena lebih mudah digunakan dan tidak memerlukan infrastruktur yang rumit bahkan meskipun diesel tidak efisien dalam biaya bahan bakar [1].

Bahan bakar tambahan menjadi alat yang penting dan sangat diperlukan tidak hanya untuk meminimalkan kelemahan cadangan listrik tetapi juga menghasilkan produk dengan spesifikasi tertentu untuk memenuhi standar regional dan internasional. Bahan bakar tambahan dapat berkontribusi terhadap penghematan bahan bakar dan pengurangan emisi baik secara langsung maupun tidak langsung [2]. Penggunaan diesel banyak di instansi seperti rumah sakit, kantor pemerintah, pusat kantor, dan terminal transportasi umum menyediakan diesel untuk memenuhi kebutuhan listrik ketika sumber listrik utama tidak cukup daya atau pembangkit listrik [3]. Permintaan diesel ini memiliki efek langsung pada 
ekonomi dan tetap menjadi pangsa dalam perdagangan diesel [4]. Perdagangan melalui media informasi adalah salah satu komponen paling relevan dari lingkungan bisnis saat ini. Mereka menawarkan peluang besar untuk sukses bagi perusahaan; mengingat bahwa mereka memiliki kemampuan mengumpulkan, mengolah, mendistribusikan, dan berbagi data secara terintegrasi [5].

Mengintergrasikan dan mengelola sebuah keputusan akan penetapan harga, dengan menjabarkan permasalahan tentang penetapan harga dan mendapatkan harga yang optimal untuk produk yang lama dan baru [6]. Penggunaan komputer dilakukan secara rutin untuk kepenting perusahaan dalam jumlah besar [7]. Dalam integrasi Sistem Informasi (SI) dan Teknologi Informasi (TI) lintas unit usaha telah menjadi tren di banyak perusahaan. Dari SI/TI yang tersebar di tiap divisi usaha secara satu sama lain, dimana duplikasi aset data yang sangat mungkin terjadi, menjadi SI/TI membutuhkan pengelolaan secara terpusat sebagai layanan umum/bersama [8]. Oleh karena itu, sistem seperti itu lebih terasa dampak intergrasi nya. Komputer dan teknologi informasi adalah hal lain yang telah ditambahkan ke dalamnya [9]. Teknologi Informasi semakin hari semakin meluas, mengubah cara kita bertukar informasi dan memperluas bidang kemungkinan suatu perencanan yang baru [10].

Perencanaan untuk proyek membutuhkan pemahaman perusahaan, analisis persyaratan bisnis, desain sistem, evolusi sistem, dan peningkatan berkelanjutan dari semua hal di atas [11]. Ini juga mencakup konsep tentang perusahaan yang diperluas, yang mencakup unit bisnis internal perusahaan bersama dengan mitra dan pemasok (kadang-kadang pelanggan juga dianggap sebagai bagian dari perusahaan yang direncanakan) [12]. Arsitektur merupakan upaya untuk melakukan tahap desain, analisis, perencanaan dan implementasi solusi bagi suatu organisasi untuk berhasil menjalankan strategi bisnis [13]. Perencanaan arsitektur merupakan pembahasan stuktur logis yang berperan untuk membantu dalam pengembangan Enterprise Architecture [14].

Pengembangan Enterprise Architecture dapat merancang organisasi yang berpusat dari rancangan bisnis proses, kebutuhan dan ketersediaan informasi, ke perencanaan sistem aplikasi [15]. Enterprise juga tugas institusional dan fungsi pendukung entitas yang memiliki tujuan bersama. Dalam hal ini, perusahaan terdiri dari beberapa divisi yang harus dikelola oleh aturan yang jelas, dan tentu saja akan membutuhkan sistem informasi yang terintegrasi. Untuk mengembangkannya, perusahaan dapat menggunakan pendekatan perencanaan arsitektur [16]. Salah satu dasar perencanaan enterprise architechture adalah mengatasi integrasi di seluruh perusahaan, melalui prinsip metode yang digunakan untuk memetakan struktur organisasi, proses bisnis, aliran informasi, sistem informasi dan infrastruktur [17-18]. Membuat konsep saat ini dapat membuat perencanaan strategis yang lebih spesifik secara langsung dengan pemodelan arsitektur [19].

Di dalam pemodelan arsitektur ada beragam cara untuk pemetaan pemodelan sebuah arsitektur salah satu nya pengenalan kerangka model ArchiMate, Archimate merupakan bahasa pemodelan standar yang dikembangkan oleh The Open Group, sebuah pemodelan industri yang mengembangkan standarisasi, untuk memberikan representasi dan menggambarkan enterprise architecture [20]. Perencanaan perlu menetapkan lima fase, yaitu 1) strategy \& motivation, 2) business layer, 3) application layer, 4) technology layer, dan 5) implementaion. Pemodelan arsitektur ini menggunakan arsitektur platform untuk memfasilitasi rancangan aplikasi order fulfillment yang dapat diwakili dengan menggunakan model ArchiMate [21].

Di perusahaan diesel ini akan mengusung perubahan proses bisnis dan akan berkerja sama dengan cabang pusat untuk menggabungkan ruang lingkup pangsa pasar, sehigga membutuhkan perencanaan aplikasi untuk memangkas waktu pengerjaan dari bertambah nya ruang lingkup dari perusahaan diesel ini.

\section{PENELITIAN YANG TERKAIT}

Pemodelan arsitektur enterprise ini mengadaptasi dari penelitian A. P. Utomo yang berjudul "Pemodelan Arsitektur Enterprise Sistem Informasi Akademik pada Perguruan Tinggi Menggunakan Enterprise Architecture Planning" [22] disitu ia membahas tentang pemodelan aplikasi menggunakan enterprise architecture, untuk membuat sebuah ruang lingkup proses bisnis yang baru menjadi terkomputerisasi. Penelitian serupa dengan framework archimate juga di buat dalam jurnal V. Cahamalda yang merancang sebuah arsitektur yang dapat membangun sebuah sistem dengan tujuan dapat meningkatkan mutu pelayanan kesehatan dengan hasik akhir berupa blueprint pemetaan dari model archimate [23].

Penelitian juga dilakukan oleh Suryadi dan J.F. Andry yang berjudul Perancangan Enterprise Architecture Mengunakan Togaf Architecture Development Method (Studi Kasus: Yakuza Gym Jakarta Barat), membahas usulan model TOGAF untuk fitness center dalam merancang EA untuk kebutuhan bisnis [24].

\section{METODE PENELITIAN}

\section{A. Archimate}

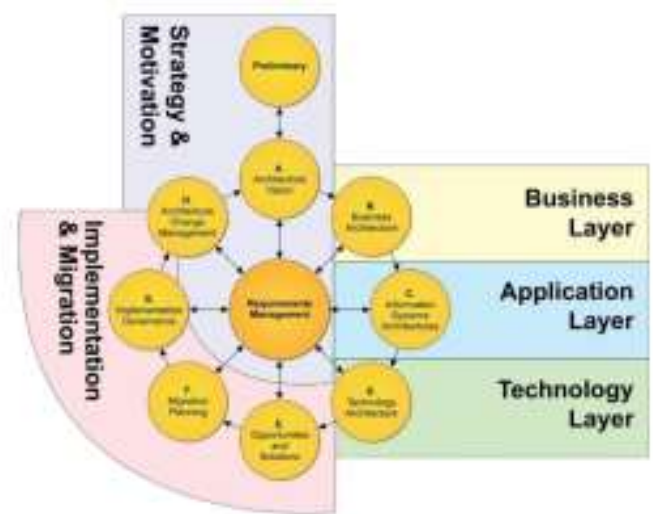

Gbr.1 Metodologi Archimate [25]

ArchiMate merupakan bahasa pemodelan dengan konsep yang menentukan arsitektur yang saling terkait, dan sudut pandang spesifik untuk stakeholder yang dipilih. Ini 
dilengkapi dengan beberapa pertimbangan mengenai mekanisme perluasan bahasa, analisis, dan dukungan metodologis. Selanjutnya, metodologi ini disertai dengan gambar akan memetakan prosedur tahapan penyelesaian masalah yang ditentukan Gbr. 1 Metodologi Archimate.

Dalam metodologi ini akan mendefinisikan komponen atau perencanaan aplikasi order fulfillment yang membentuk sistem informasi secara keseluruhan, pengembangan subsistem yang telah ada di perusahaan diesel ini untuk dikembangkan. Untuk metodologi ini akan menjelaskan bagian Application Layer saja, dengan demikian memungkinkan untuk mengelola keseluruhan investasi teknologi informasi dengan cara yang memenuhi kebutuhan bisnis. Untuk memberikan representasi pemakaian sistem, yang menggambarkan suatu perencanaan aplikasi dengan metodologi ArchiMate.

\section{B. Application Layer}

Mendukung lapisan bisnis dengan layanan aplikasi yang diwujudkan oleh aplikasi (perangkat lunak). Application layer akan menjabarkan segala perencanaan fungsi spesifik dari aplikasi yang akan di uraikan kedalam pembahasan untuk memaparkan kebutuhan menjadi sebuah aplikasi untuk di operasikan oleh si pengguna. Ada hubugan antara proses bisnis dan elemen aplikasi, untuk saling mengintergrasikan segala kebiatan proses bisnis untuk mendokumentasikan segala laporan dan untuk tahapan perencanaan selanjutnya akan di petakan di Gbr. 2 Application Layer Process.

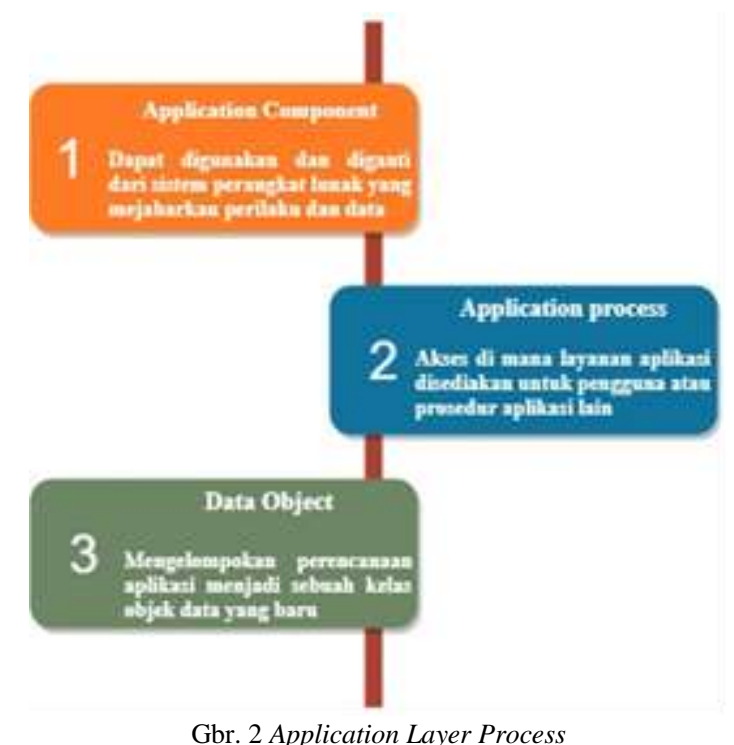

Dari proses ini akan menghasilkan sebuah perencanaan berupa:

\section{1) Application Component}

Proses ini akan menggunakan komponen aplikasi yang lama yang di komparasi menjadi sebuah komponen aplikasi yang baru

2) Application Process

Proses ini akan menjabarkan prosedur penggunaan yang di sediakan di perencanaan aplikasi ini

\section{3) Data Object}

Proses ini akan mengelompokkan perencanaan komponen aplikasi yang baru menjadi sebuah objek yang bisa menjadikan sebuah entitas dari sistem perencanaan

\section{HASIL DAN PEMBAHASAN}

\section{A. Application Component}

Di perusahaan diesel sebelumnya sudah mempunyai aplikasi dalam menunjang proses bisnis di dalam perusahaan untu mengelola data sebagai menjadi pelaporan untuk mengevaluasi sebuah keuntungan dan kerugian. Komponen dari aplikasi akan merepresentasikan dari aplikasi yang akan di gunakan oleh user untuk membagi tugas dan pembuatan laporan di perencanaan aplikasi order fulfillment yang bisa memangkas pembuatan laporan, dengan adanya komponen aplikasi ini akan menghasilkan modul baru. Ini merupakan pendekatan berbasis penggunaan kembali untuk mendefinisikan, mengimplementasikan dan menyusun komponen independen yang digabungkan ke dalam sistem. Pembahasan ini bertujuan untuk membawa tingkat manfaat yang sama baik dalam jangka pendek dan jangka panjang untuk perangkat lunak itu sendiri dan untuk aplikasi tersebut. Semua proses sistem ditempatkan ke dalam komponen yang terpisah sehingga semua data dan fungsi di dalam masingmasing komponen terkait secara semantik (seperti halnya dengan isi kelas data). Karena pembahasan ini, sering dikatakan bahwa komponen bersifat modular. Berdasarkan data yang ada di wawancara pengembangan arsitektur, kami menyimpulkan beberapa sebuah pengembangan aplikasi yang baru untuk menunjang visi misi kedalam proses bisnis dan hal itu dapat di jabarkan dalam pembahasan sebagai berikut:

1) Pengaturan aplikasi Penjualan

- Perencanaan aplikasi penjualan

a. Mengatur data faktur penjualan

b. Mengatur data penjualan

c. Mengatur data pelanggan

d. Mengatur data laporan penjualan

2) Pengaturan aplikasi Gudang

- Perencanaan aplikasi Gudang
a. Mengatur data suku cadang diesel
b. Mengatur data kualitas cek
c. Mengatur data customer service
d. Mengatur data penyusutan barang
e. Mengatur laporan gudang

3) Pengaturan aplikasi pembelian

- Perencanaan aplikasi pembelian
a. Mengatur data pembelian barang
b. Membuat surat pengadaan barang
c. Membuat laporan pembelian

4) Pengaturan aplikasi akuntansi keuangan

- Perencanaan aplikasi akunting

a. Mengatur data jurnal akunting

b. Mengatur harga pokok produksi

c. Mengatur laporan stok

d. Mengatur laporan keuangan

- Perencanaan aplikasi keuangan 
a. Mengatur data transaksi kas

b. Mengatur laporan transaksi kas

c. Mengatur data transaksi bank

d. Mengatur laporan transaksi bank

e. Mengatur data pajak

f. Mengatur laporan pajak

5) Perencanaan aplikasi admin

- Perencanaan aplikasi admin

a. Mengelola data semua divisi

b. Memastikan sistem dari aplikasi order fulfillment berjalan dengan memestinya

Dari pembahasan ini dipilih nya aplikasi order fulfillmet, di karenakan order fulfillment dapat memangkas waktu pengerjaan laporan yang di butuhkan oleh perusahaan agar bias meningkat rantai pasok manajemen bisnis. Aplikasi lama akan dikembangkan menjadi sebuah perencanaan yang mengikuti langkah metologi archimate, komponen berkomunikasi satu sama lain melalui antarmuka. Ketika sebuah komponen menawarkan layanan ke seluruh sistem, mengadopsi perencanaan yang disediakan yang menentukan layanan yang dapat digunakan komponen lain, dan bagaimana dapat merealisasikanya. Aplikasi ini dapat dilihat sebagai tanda tangan komponen user tidak perlu tahu tentang cara kerja bagian dalam komponen (implementasi) untuk memanfaatkannya. namun di tambahnya aplikasi lama akan menjadi sebuah komponen aplikasi yang baru untuk di komparasi menjadi bagian sistem yang di usulkan dan akan dijabarkan kedalam Gbr. 3 Application Component Order Fulfillment.

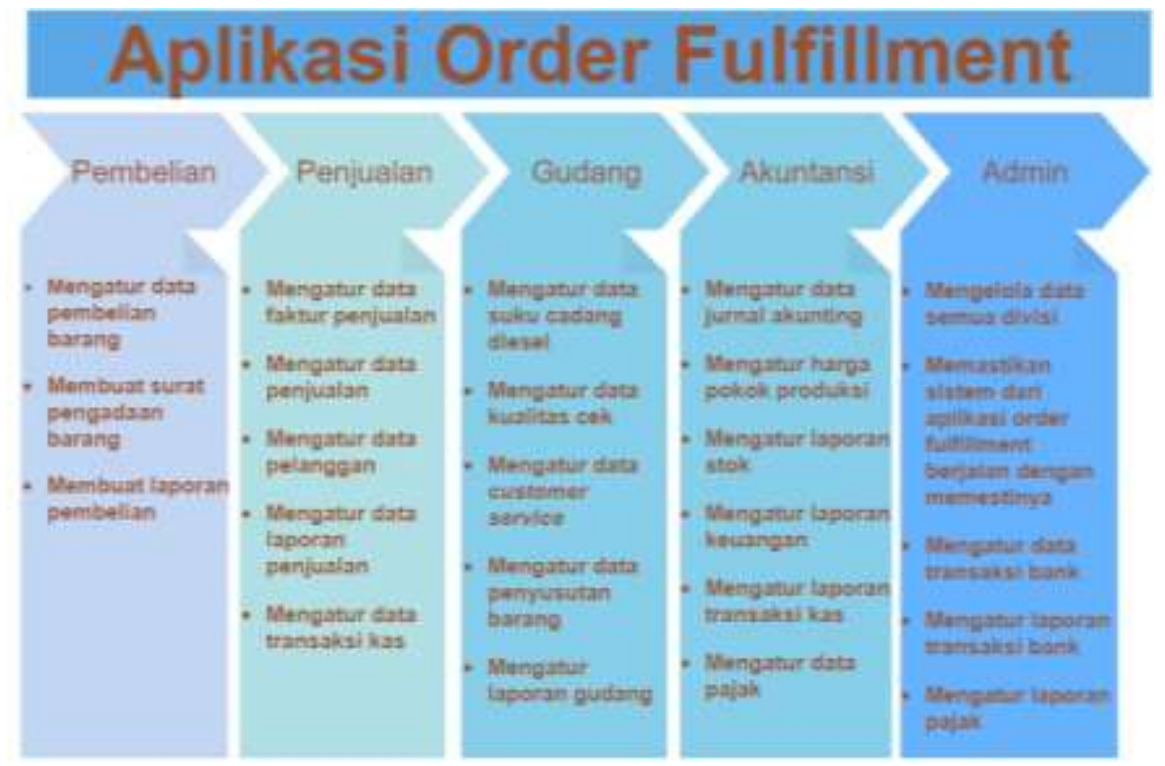

Gbr. 3 Application Component Order Fulfillment

\section{B. Application proses}

Dari pemaparan diatas yang mengelompokan sebuah komponen aplikasi, tahapan ini akan membahas proses dari komponen aplikasi yang sudah di jabarkan di pembahasan sebelumnya, untuk proses ini akan menjelaskan prosedur penggunaan aplikasi dan layanan pendukung yang akan di Analisa melalui Tabel I. Projek dan Layanan Pendukung.

TABEL I

PROJEK DAN LAYANAN PENDUKUNG

\begin{tabular}{|l|l|c|}
\hline \multicolumn{1}{|c|}{ Project } & \multicolumn{1}{|c|}{ Benefit } & Requirement \\
\hline & $\begin{array}{l}\text { Semakin baik desain } \\
\text { database dilakukan, }\end{array}$ & \\
Mengembangkan & semakin banyak akan & Microsoft \\
Migrasi Data & meningkatkan & Access \\
& $\begin{array}{l}\text { kecepatan, keakuratan, } \\
\text { dan keakuratan dalam } \\
\text { memperoleh informasi }\end{array}$ & \\
\hline Developing & Meningkatkan & C\# (Sharp) \\
\hline
\end{tabular}

\begin{tabular}{|c|c|c|}
\hline service & $\begin{array}{l}\text { fleksibilitas, dan juga } \\
\text { mengurangi } \\
\text { redundansi }\end{array}$ & \\
\hline $\begin{array}{l}\text { Migrasi aplikasi } \\
\text { konvensional ke } \\
\text { aplikasi yang di } \\
\text { usulkan }\end{array}$ & $\begin{array}{l}\text { Memangkas waktu } \\
\text { pengerjaan laporan }\end{array}$ & $\begin{array}{l}\text { Microsoft } \\
\text { Access, C\# } \\
\text { (Sharp) }\end{array}$ \\
\hline $\begin{array}{l}\text { Mengembangkan } \\
\text { arsitektur } \\
\text { perusahaan }\end{array}$ & $\begin{array}{l}\text { Ketersediaan } \\
\text { dokumentasi arsitektur } \\
\text { perusahaan sebagai } \\
\text { referensi untuk } \\
\text { mengembangkan } \\
\text { arsitektur perusahaan } \\
\text { yang berkelanjutan }\end{array}$ & Archimate \\
\hline
\end{tabular}

Dari Table I. Projek dan layanan pendukung ada kebutuhan yang harus di dukung untuk perencanaan aplikasi ini yaitu Microsoft access, C\# (Sharp). Layanan pendukung tersebut harus di kuasai oleh programing dalam pembuatan 
aplikasi order fulfillment, Bahasa program C\# (Sharp) tersebut mempunyai tingkat keamanan yang tinggi di karenakan bahasa program tersebut jarang ada orang yang menguasai bahasa tersebut dan baik dalam membangun pengembangan aplikasi desktop yang tidak membutuhkan migrasi ke dalam pemodelan bahasa pemograman lainya. Dengan di tentukan nya C\# (Sharp) menjadi bahasa pemograman di aplikasi tersebut dan menggunakan visual studio dalam mengeksekusi jalanya program yang sudah di buat dalam tahap coding oleh programer, database yang akan di usulkan dalam penyimpanan semua laporan yang sudah di buat akan di alokasikan kedalam database micosoft access, di samping pemakaian nya mudah database tersebut bisa di gunakan dalam paket micosoft office.

\section{Data Object}

Data object pada pembahasan ini akan menyimpulkan segala uraian perencanaan aplikasi menjadi sebuah objek data untuk mengintergrasikan sebuah fitur yang ada di dalam sistem tersebut untuk memetakan hak akses dari setiap divisi untuk permasalahan modul yang kompleks dapat di deklarasikan dengan operasi - operasi yang penting yang dapat di eksekusi lebih cepat, berikut akan di jabarakan di dalam Tabel II. Uraian Data Order Fulfillment.

TABEL III

URAIAN DATA ORDER FULFILLMENT

\begin{tabular}{|c|c|}
\hline Fitur & Uraian \\
\hline \multirow[t]{8}{*}{ Gudang } & Data Barang Masuk \\
\hline & Data Barang Keluar \\
\hline & Laporan barang masuk \\
\hline & Laporan barang keluar \\
\hline & Hitung ulang stok barang \\
\hline & Kartu stok barang \\
\hline & Data cutomer service \\
\hline & Laporan penyusutan barang \\
\hline \multirow{4}{*}{ Pembelian } & Order pembelian \\
\hline & Detil pengiriman \\
\hline & Laporan pembelian \\
\hline & Surat pengadaan barang \\
\hline \multirow{5}{*}{ Penjualan } & Order penjualan \\
\hline & Faktur Penjualan \\
\hline & Laporan per bulan \\
\hline & Laporan pengiriman order \\
\hline & Transaksi kas \\
\hline \multirow{7}{*}{ Akuntansi } & Laporan buku besar \\
\hline & Laporan neraca \\
\hline & Laporan laba rugi \\
\hline & Laporan transaksi kas \\
\hline & Data pajak \\
\hline & Hitung barang suku cadang \\
\hline & Laporan suku cadang \\
\hline \multirow{4}{*}{ Admin } & Data pemakai dan wewenang \\
\hline & Transaksi bank \\
\hline & Laporan bank \\
\hline & Laporan pajak \\
\hline
\end{tabular}

Fitur dan uraian aplikasi order fulfillment ini merupakan keterangan dan fungional pemakaian atribut pada saat pemakaian modul dan penggunaan aplikasi tersebut:

1) Gudang

- Data barang masuk terdiri dari: Kode barang, Nama barang, Kuantitas, Harga, Nomor bukti, Nomor purchase order, Tanggal

- Data barang keluar: Nama barang, Kode barang, Kuantitas, Nomor bukti, Tanggal

- Laporan barang masuk: Kode barang, Nama barang, Kuantitas, Harga, Nomor bukti, Nomor purchase order, Tanggal

- Laporan barang keluar: Nama barang, Kode barang, Kuantitas, Nomor bukti, Tanggal, Kartu stok barang, Kode barang, Periode, Tanggal, Barang masuk, Barang keluar, Sisa

- Hitung ulang stok barang: Nomor bukti, Tanggal, Barang masuk, Barang keluar, Posisi stok

- Data customer service: Nama perusahaan, Tipe customer, Id customer, Alamat, Nomor telefon 1, Nomor telefon 2, Email

- Laporan penyusutan barang: Kode barang, Nama barang, Tanggal pembelian, Harga beli, Akomodasi penyusutan

2) Pembelian

- Order pembelian: Nomor order, Tanggal order, Tanda terima, Catatan spesifikasi, Harga, Deskripsi, Jumlah, Sub total

- Detil pengiriman: Tanggal kirim, Nomor order, Status pengiriman, Tanda terima, Harga, Nama supplier, Subtotal

- Laporan pembelian: Kode barang, Jumlah, Harga, Sub total, Tanggal kirim, Nama supplier

- Surat pengadaan: Kode barang, Jumlah, Nama, Jabatan, Alamat, Perusahaan, Tipe barang, Nama barang, Tanggal pengadaan

3) Penjualan

- Order penjualan: Nomor order, Nomor bukti, Nomor customer, Nama customer, Tanggal jual

- Faktur penjualan: Nomor faktur, Tanggal jual, No bukti, Nama customer, Nomor customer, Nomor order

- Laporan per bulan: Bulan, Nomor order, Nomor bukti, Harga total, Kuantitas, Tanggal order, Harga ppn, Nomor urut, Nomor faktur, Nama barang, Keterangan

- Laporang pengriman order: Tanggal jual, Nama barang, Kode barang, Nomor pengiriman, Kuantitas, Nama customer, Kode customer

- Transaksi kas

- Penerimaan kas: Keterangan, No akun, Jenis, Saldo, Nama akun

- Pengeluaran kas: Keterangan, Nomor akun, Saldo, Nama akun, Jenis 
4) Akuntansi

- Laporan bukus besar: Nomor bukti, Tanggal, Jenis, Keterangan, Nomor akun, Debet, Kredit, Sisa

- Laporan neraca: Aktiva lancar, Aktiva tetap, Jumlah, Kas, Peralatan, Sewa dibayar di muka, Pajak di bayar di muka, Modal saham, Gedung, Kendaraan

- Laporan transaksi kas: Kas keluar, Keterangan, Nomor akun, Jenis, Saldo, Nama akun, Kas masuk, Keterangan, Nomor akun, Jenis, Saldo, Nama akun, Selisih kas

- Data pajak: Masa pajak, Npwp, Nama, Alamat, Penerima penghasilan, Kode pajak, Jumlah penerima, Jumlah penghasilan, Jumlah pajak di potong

- Hitung barang suku cadang: Kode barang, Nama barang, Kuantitas masuk, Kuantitas keluar, Saldo keluar, Saldo masuk, Laporan suku cadang, Kode barang, Nama barang, Kuantitas masuk, Kuantitas keluar, Saldo keluar, Saldo masuk

5) Admin

- Data pemakai dan wewenang: Nama pemakai, Kata sandi, Daftar akses

- Transaksi bank

o Penerimaan bank: Keterangan, Nomor akun, Jenis, Saldo, Nama akun

- Pengeluaran bank: Keterangan, Nomorakun, Jenis, Saldo, Nama akun

- Laporan pajak: Masa pajak, Npwp, Nama, Alamat, Penerima penghasilan, Kode pajak, Jumlah penerima, Jumlah penghasilan, Jumlah pajak di potong

Dari pengelompokan dan fungsional diatas harus memiliki sebuah wewenang pada hak akses penggunaan aplikasi dan setiap divisi akan mempunyai data pemakai untuk mengetahui siapa saja yang yang mengoperasikan penggunaan aplikasi tersebut dan menghindari perububahan laporan yang jarang di ketahui. Aplikasi ini juga dapat mengembangan pemenuhan pesanan untuk mendapatkan pengukuran yang tepat.

\section{KESIMPULAN}

Pemodelan aplikasi order fulfillment yang telah dilakukan dengan mengusulkan enterprise architechture architame untuk di terapkan kedalam model bisnis yang di gunakan yakni modul gudang, modul pembelian, modul penjualan, modul admin dan modul akuntansi dapat di simpulkan dengan cara penerapan aplikasi ini di harapkan dapat membantu perusahaan diesel ini mencegah di ubah nya laporan dan memangakas efisiensi waktu pengerjaan. Dengan adanya penelitian ini di harapkan bisa menerapkan objek dari modul penggunaan aplikasi order fulfillment.

\section{DAFTAR PUSTAKA}

[1] K. Bhavani and S. Murugesan, "Diesel to Dual Fuel Conversion Process Development," International Journal of Engineering \& Technology, vol. 7, 2018.
[2] H. K. Rashedul, H. H. Masjuki, M. A. Kalam, A. M. Ashraful and S. A. Shahir, "The Effect of Additives on Properties, Performance and Emissionof Biodiesel Fuelled Compression Ignition Engine," Energy Conversion and Management, vol. 88, 2014.

[3] Q. Tan, Y. Hu, X. Zhang and H. Zhang, "A Study on the Combustion Performance of Diesel Engines with $\mathrm{O} 2$ and $\mathrm{CO} 2$ Suction," Journal of Chemistry, 2016.

[4] K. Nanthagopal, B. Ashok, R. T. K. Raj, S. Jathar, K. J. Samuel, R. Khrishnan, T. Sathyanand and S. Logesh, "Lemon Essential oil -A Partial Substitute for Petroleum Diesel Fuel in Compression Ignition Engine," International Journal of Renewable Energy Research, vol. 7, no. $2,2017$.

[5] X. Li, "Operations Management of Logistics and Supply Chain: Issues and Directions," Discrete Dynamicsin Nature and Society, 2014.

[6] D. Abrego, Y. S. Tovar and J. M. M. Quintero, "Influence of Information Systems Onorganizational Results," Contaduría y Administración, vol. 62, 2017.

[7] E. C. Ramdhani, H. Gaja and Ratnawati," Aplikasi Berbasis Dekstop Untuk Persediaan Bahan Baku Produksi Menggunakan Model Waterfall (Study Kasus: PT. Seyon Indonesia), Jurnal Informatika: Jurnal Pengembangan IT (JPIT), Vol.03, No.02, Mei 2018

[8] V. Leonardo and B. Yuwono, "Tatakelola Teknologi Informasi Dalam Rangka Integrasi Sistem Dan Teknologi Informasi Lintas Anak Perusahaan," Journal of Information Systems, vol. 5, 2009.

[9] S. Raeisi, "Implementation Management Information System (MIS) inthe Tehran Vehicle Technical Inspection Bureau," International Academic Institute for Science and Technology, vol. 3, no. 10, 2016.

[10] B. Fritscher and Y. Pigneur, "Business IT Alignment from Business Model to Enterprise Architecture," 2014.

[11] B. D. Rouhani, M. N. Mahrin, F. Nikpay, R. B. Ahmad and P. Nikfard, "A Systematic Literature Review on Enterprise Architectureimplementation Methodologies," information and Software Technology, vol. 62, 2015.

[12] Taylor \& Francis Group, "Enterprise ArchitectureA to Z," 2008.

[13] Y. Ruldeviyani, E. Wisnuwardhani and Y. G. Sucahyo, "Designing Enterprise Architecture: Case Study of the Ministry of Energy and Mineral Resources," Journal of Engineering and Applied Sciences, vol. 12, 2017.

[14] N. Safitri and R. Pramudita, "Pengembangan Kerangka Kerja Arsitektur Enterprise," Bina Insani ICT Journal, vol. 4, no. 1, 2017.

[15] E. Amalia and H. Supriadi, "Development of Enterprise Architecture in University Using TOGAF as Framework," 2017.

[16] M. E. Haloui, H. Kriouile and A. Kriouile, "Towards Services-Based Enterprise Architecture for Cloud Computing-Opened Information Systems," Journal of Computer, vol. 10, no. 3, 2015.

[17] A. Aldea, M. E. Iacob, J. V. Hillegersberg, D. Quartel, L. Bodenstaff and H. Franken, "Modelling Strategy with Archimate," 2015.

[18] J. F. Andry and Reinaldo, "Order Fulfillment System for Small Medium Business," Journal of Business and Audit Information Systems, vol. 1, no. 1, 2018.

[19] F. Rahimi, J. Gotze and C. Moller, "Enterprise Architecture Management: Toward aTaxonomy of Applications," Communications of the Association for Information Systems, vol. 40, 2017.

[20] N. Mayer and C. Feltus, "Evaluation of the Risk and Security Overlay of ArchiMate to model Information System Security Risks," 2017.

[21] F. Aulkemeier, M. E. Iacob and J.V. Hillergersberg," An Architectural Perspective On Service Adoption: A Platform Design and The Case of Pluggable Cross-Border Trade Compliance In E-Commerce," Journal of Organizational Computing and Electronic Commerce, vol. 27, no. 27,2017

[22] A. P. Utomo, "Pemodelan Arsitektur Enterprise Sistem Informasi Akademikpada Perguruan Tinggi Menggunakan Enterprise Architecture planning," Jurnal SIMETRIS, vol.5 no. 1, 2014.

[23] V. Cahamalda, Zulfiandri and G. M. Nur, "Perencanaanarsitektur Enterprise Denganmetode Togaf Versi 9 (Studikasus: Rumahsakitumum Kotatangerang Selatan)," Studia Informatika: Jurnal Sistem Informasi, 2017.

[24] Suryadi and J. F. Andry, "Perancangan Enterprise Architecture Mengunakan Togaf Architecture Development Method (Studi Kasus: Yakuza Gym Jakarta Barat), Seminar Nasional Teknoka, Vol. 2, 2017.

[25] Open Group Standard “Archimate 2.0 Specification," 2012. 